\title{
Linkage and association of an interleukin 4 gene polymorphism with atopic dermatitis in Japanese families
}

Tomoko Kawashima, Emiko Noguchi, Tadao Arinami, Kimiko Yamakawa-Kobayashi, Hidemi Nakagawa, Fujio Otsuka, Hideo Hamaguchi

\begin{abstract}
We examined linkage between markers at and near the IL4 gene and atopic dermatitis (AD) in 88 Japanese nuclear families. Affected sib pair analysis suggested linkage between the IL4 gene and AD (SPLINK lod=2.28). Transmission disequilibrium testing showed a significantly preferential transmission to $\mathrm{AD}$ offspring of the $T$ allele of the $-590 \mathrm{C} / \mathrm{T}$ polymorphism of the IL4 gene $(p=0.001)$. A case-control comparison suggested a genotypic association of the TT genotype with $A D$ (odds ratio $=1.88, p=0.01$ ). Since the $T$ allele was reported to be associated with increased IL4 gene promoter activity compared with the $\mathbf{C}$ allele, our data indicate that genetic differences in transcriptional activity of the IL4 gene influence $A D$ predisposition, particularly in Japanese, because of a high frequency of the $\mathrm{T}$ allele. $(\Im$ Med Genet 1998;35:502-504)
\end{abstract}

Keywords: interleukin-4 gene; atopic dermatitis; linkage; transmission disequilibrium test

Department of

Paediatrics, Institute

of Clinical Medicine,

University of Tsukuba,

Ibaraki 305, Japan

E Noguchi

Department of

Medical Genetics,

Institute of Basic

Medical Sciences,

University of Tsukuba,

Ibaraki 305, Japan

T Arinami

K Yamakawa-Kobayashi

H Hamaguchi

Department of

Dermatology, Jichi

Medical School,

Tochigi 329-04, Japan

H Nakagawa

Correspondence to:

Dr Arinami.

Received 8 October 1997 Revised version accepted for publication

4 December 1997 gene markers in the cytokine gene cluster, including the IL4 gene on chromosome 5q3133 , has been reported, ${ }^{78}$ though subsequent $\mathrm{AD}$ are reported to secrete increased amounts of IL4. ${ }^{45}$ A recent study indicated that IL4 mRNA expression is increased in $\mathrm{AD}$ skin 列 lved skin of patients with $\mathrm{AD} .^{6}$

Linkage between total serum IgE levels, multi-allergen IgE antibody, or bronchial activating the pre-T helper cells to Th2 cells that trigger isotype switching from IgM/IgG to (VCAM1), an adhesion molecule involved in nophils into sites of tissue inflammation. ${ }^{2}$ II 4 also been shown to inhibit producto interferon- $\gamma$ (IFN- $\gamma$ ), which inhibits IgE synthesis, and downregulates the differentiation of Th1 cells. ${ }^{3}$ Lymphocytes from patients with studies failed to find evidence for linkage between $5 \mathrm{q}$ markers and atopic phenotypes..$^{9-12}$ Rosenwasser et $a l^{13}$ reported that the IL4 promoter polymorphism, a $\mathrm{C}$ to $\mathrm{T}$ change at position -590 counting from the first ATG codon, is associated with total serum IgE levels and asthma.

There have been only a few linkage studies in AD. Chromosome 11q13 was excluded as a major susceptibility locus for AD. ${ }^{14}$ Weak association between genetic variants of the mast cell chymase gene and eczema has been reported in the Japanese. ${ }^{15}$ No studies of the linkage between $\mathrm{AD}$ and the $5 \mathrm{q}$ region and the IL4 promoter polymorphism have been reported. In this study, we investigated linkage and association between gene markers on 5q31-q33 and AD in Japanese AD families.

A panel of 377 subjects from 88 families was ascertained through at least two $\mathrm{AD}$ sibs undergoing treatment for $\mathrm{AD}$ at clinics in Ibaraki and Tokyo, Japan. The diagnosis of $\mathrm{AD}$ was made based on the appearance of active skin disease, distribution of skin lesions, and clinical course of the disease. All of the sibs analysed met the diagnostic criteria of Hanifin and Rajka. ${ }^{16}$ The AD sibs included 93 males and 108 females aged from 1 to 38 years (mean 10 years). The control subjects were 215 children from Ibaraki, Japan aged 11 years with no history of AD. All of the control subjects were unrelated Japanese. All subjects gave informed consent. This study was approved by the Committee of Ethics at the University of Tsukuba.

Genomic DNA was extracted from peripheral blood leucocytes or mucous membrane

Table 1 Results of linkage analyses in affected pairs of sibs with atopic dermatitis

\begin{tabular}{|c|c|c|c|c|c|}
\hline \multirow[b]{2}{*}{ Marker } & \multirow{2}{*}{$\begin{array}{l}\text { KcM from } \\
\text { pter }\end{array}$} & \multicolumn{2}{|c|}{ SPLINKt } & \multicolumn{2}{|c|}{ GENEHUNTER } \\
\hline & & Lod & $p$ & NPL & $p$ \\
\hline IL4 & 144 & 2.28 & 0.001 & 2.34 & 0.009 \\
\hline IL9 & 148 & 0.69 & 0.05 & 1.19 & 0.12 \\
\hline D5S399 & 152 & 0.16 & 0.25 & 1.69 & 0.04 \\
\hline D5S436 & 159 & 0.39 & 0.12 & 1.58 & 0.05 \\
\hline D5S434 & 164 & 0.09 & 0.33 & 1.54 & 0.06 \\
\hline
\end{tabular}

^From Genethon-chromosome 5 (1996).

tMore than two affected sibs were weighted by $2 / n(n=$ the number of affected sibs) 
Table 2 Genotypic and allelic distributions of the IL4-590C/T polymorphism in Fapanese unrelated controls and patients with atopic dermatitis

\begin{tabular}{|c|c|c|c|c|c|c|}
\hline & \multirow[b]{2}{*}{ No } & \multicolumn{3}{|l|}{ Genotype } & \multicolumn{2}{|l|}{ Allele } \\
\hline & & $C C$ & $C T$ & $T T$ & $C$ & $T$ \\
\hline $\begin{array}{l}\text { Controls } \\
\text { AD parents } \\
\mathrm{AD} \text { offspring } \\
\text { Odds ratio } \\
95 \% \text { confidence interval } \\
\text { p value }\end{array}$ & $\begin{array}{l}215 \\
122 \\
88\end{array}$ & $\begin{array}{l}17(0.08) \\
7(0.06) \\
8(0.09) \\
1.16 \\
0.52-2.78 \\
0.73\end{array}$ & $\begin{array}{l}97(0.45) \\
57(0.47) \\
25(0.28) \\
0.48 \\
0.29-0.83 \\
0.007\end{array}$ & $\begin{array}{l}101(0.47) \\
58(0.48) \\
55(0.63) \\
1.88 \\
1.13-3.09 \\
0.01\end{array}$ & $\begin{array}{l}131(0.30) \\
71(0.29) \\
41(0.23)\end{array}$ & $\begin{array}{l}299(0.70) \\
173(0.71) \\
135(0.77) \\
1.44 \\
0.69-2.14 \\
0.08\end{array}$ \\
\hline
\end{tabular}

$\mathrm{C}$ corresponds to the $-590 \mathrm{C}$ allele and $\mathrm{T}$ corresponds to the $-590 \mathrm{~T}$ allele.

* Parents with history of atopic diseases were excluded.

p values were calculated using $2 \times 2$ chi square test. $p$ values of genotypes were based on one genotype $v$ all other genotypes combined. The genotype distributions did not deviate significantly from those based on Hardy-Weinberg equilibrium in each group $\left(\chi^{2}=0.91\right.$, $\mathrm{p}=0.34$ in the controls; $\chi^{2}=2.14, \mathrm{p}=0.14$ in the $\mathrm{AD}$ parents; $\chi^{2}=3.70, \mathrm{p}=0.054$ in the $\mathrm{AD}$ offspring).

cells from the mouth using standard phenol extraction techniques. DNA samples from $\mathrm{AD}$ families were genotyped for five microsatellite DNA markers on chromosome 5q using PCR primers and conditions described elsewhere. ${ }^{7}$

All DNA samples were tested for the $-590 \mathrm{C} / \mathrm{T}$ IL4 gene polymorphism by the PCRRFLP (restriction fragment length polymorphism) method. The region of interest was amplified by PCR with a primer pair (5'TAAACTTGGGAGAACATGGT and 5'TGGGGAAAGATAGAGTAATA) at $93^{\circ} \mathrm{C}$ for five minutes, followed by 36 cycles of melting at $93^{\circ} \mathrm{C}$ for 60 seconds, annealing at $48^{\circ} \mathrm{C}$ for 60 seconds, and an extension of $72^{\circ} \mathrm{C}$ for 60 seconds, followed by $72^{\circ} \mathrm{C}$ for three minutes. The PCR product is $195 \mathrm{bp}$ and spans positions -562 to -756 in the IL-4 promoter sequence. The PCR products were digested with AvaII, denatured, and run on a urea $6 \%$ polyacrylamide gel at $60 \mathrm{~W}$ for three hours. The gels were dried and autoradiographed.

Non-parametric affected sib pair linkage analysis using the SPLINK (version 1.07) ${ }^{17}$ and multipoint non-parametric analysis using the GENEHUNTER (version 1.2) ${ }^{18}$ programs were performed. Sibships containing more than one pair were weighted in SPLINK. Linkage results were interpreted according to the guidelines proposed by Lander and Kruglyak. ${ }^{19}$ The transmission disequilibrium test (TDT) was performed using the ASSTDT program in the Genetic Analysis System (GAS version 2.0: A Young, University of Oxford, 1993-1995) available at http://users.ox.oc.uk/ ayoung/ gas.html. In case-control comparisons, the oldest offspring with $\mathrm{AD}$ from each unrelated family was selected and compared with unrelated control subjects, since at least two $\mathrm{AD}$ offspring per family were probands.

Suggestive evidence for linkage between $\mathrm{AD}$ and the polymorphic IL4 marker was obtained with SPLINK (lod score 2.28) and GENEHUNTER (NPL score 2.37) programs (table 1). No evidence for linkage was obtained with markers at IL9, D5S399, D5S436, or D5S434. The calculated information content by GENEHUNTER was from 0.7 to 0.85 .

TDT indicated that no alleles of the microsatellite polymorphic markers at IL4, IL9, D5S399, D5S436, or D5S434 significantly deviated from the expected ratio of $1: 1$ transmission to $\mathrm{AD}$ offspring ( $\mathrm{p}>0.05$, data not shown). The T allele of the $-590 \mathrm{C} / \mathrm{T}$ IL4 gene polymorphism was significantly preferentially transmitted to the $\mathrm{AD}$ offspring: $86 \mathrm{~T}$ alleles were transmitted and $50 \mathrm{~T}$ alleles were not transmitted ( $p=0.0014$, based on binomial distribution, one sided). Since preferential transmission of the $\mathrm{T}$ allele to $\mathrm{AD}$ offspring was observed, we examined the allele distribution in the control subjects. Comparisons of genotypic and allelic distribution between the $\mathrm{AD}$ patients and controls showed a significant increase in the number of $T$ allele homozygotes $(p=0.01)$ and a non-significant increase in the $T$ allele $(p=0.08)$ in the $A D$ cases compared with the controls (table 2 ).

To date, studies on linkage between gene markers on 5q31-q33 and atopy have yielded conflicting results. An association between the $-590 \mathrm{C} / \mathrm{T}$ polymorphism and serum total IgE levels was reported by Rosenwasser et al, ${ }^{13}$ but this association was not replicated by Walley and Cookson. ${ }^{20}$ However, the latter observed a weak association of the polymorphism with specific IgE to house dust mite and with wheezing and a non-significant trend of increased $T$ allele frequency in asthmatics compared to controls. Therefore, we feel that our results are not inconsistent with those of Walley and Cookson, ${ }^{20}$ though the degree of the association differs: linkage between atopy and 5q31-q33 was not observed in the families Walley and Cookson examined, ${ }^{21}$ while linkage between the IL4 gene and AD was observed in our families. This may result from racial differences in the IL4 allele frequencies, which are significant between whites and Japanese: the $T$ allele frequency was 0.7 in Japanese controls, 0.26 in Australian controls, and 0.27 in white UK controls. In the present study, homozygosity for the $\mathrm{T}$ allele was associated with $\mathrm{AD}$, indicating the greater importance of the $-590 \mathrm{C} / \mathrm{T}$ polymorphism in $\mathrm{AD}$ in Japanese than white populations. Since the $T$ allele is reported to be associated with higher IL4 gene promoter activity than the $\mathrm{C}$ allele, we speculate that genetic differences in transcriptional activity of the IL4 gene influence AD predisposition in the Japanese.

We thank Drs S Okabe, O Urushibata, R Muraki, N Nogi, S Iijima, T Higuchi, T Takase, T Yoshii, T Maki, M Hoshino, $M$ Tanaka, N Suzuki, Y Saito, H Matsumoto, T Shibahara, K Sakou, H Fujisawa, M Sakuma, Y Matsushima, E Ichikawa, Y Tsubouchi, and $M$ Ito for collection of families and the families who participated in this study for their cooperation. 
1 Vercelli D, Geha RS. Regulation of IgE synthesis: from membrane to the genes. Springer Semin Immnunopathol 1993;15:5-16

2 Schleimer RP, Sterbinsky SA, Keiser J, et al. Interleukin-4 induces adherence of human eosinophils and basophils but not neutrophils to endothelium: association with expression of VCAM-1. F Immunol 1992;148:1086-92.

3 Vercelli D, Jabara HH, Lauener RP, et al. IL-4 inhibits the synthesis of IFN-gamma and induces the synthesis of IgE in human mixed lymphocyte cultures. $\mathcal{F}$ Immunol 1990;144: 570-3.

4 Rousset F, Robert J, Andary M, et al. Shifts in interleukin-4 and interferon-gamma production by $\mathrm{T}$ cells of patients with elevated serum IgE levels and the modulatory effects of these lymphokines on spontaneous IgE synthesis. $f$ Allergy Clin Im

5 Renz H, Jujo K, Bradley KL, et al. Enhanced IL-4 production and IL-4 receptor expression in atopic dermatitis and their modulation by interferon-gamma. F Invest Dermatol 1992;99:403-8.

6 Hamid Q, Boguniewicz M, Leung DY. Differential in situ cytokine gene expression in acute versus chronic atopic dermatitis. 7 Clin Invest 1994;94:870-6.

7 Marsh DG, Neely JD, Breazeale DR, et al. Linkage analysis of IL4 and other chromosome 5q31.1 markers and total serum immunoglobulin E concentrations. Science 1994; 264:1152-6.

8 Meyers AD, Postma DS, Panhuysen CIM, et al. Evidence for a locus regulating total serum IgE levels mapping to for a locus regulating total serum IgE leve

9 Blumenthal MN, Banks SS, Bleecker ER, et al. Collaborative studies on the genetics of asthma-National Heart Lung and Blood Institute. Clin Exp Allergy 1995;2:29-32.

10 Stanford AJ, Daniels SE, James AL. Chromosome 5 markers, total serum IgE and bronchial hyperresponsiveness in a random population. Am $\mathcal{F}$ Respir Med Crit Care Med 1995;151:A341.
11 Doull IJ, Lawrence S, Watson M, et al. Allelic association of gene markers on chromosomes $5 \mathrm{q}$ and $11 \mathrm{q}$ with atopy and bronchial hyperresponsiveness. Am 7 Respir Crit Care Med 1996;153:1280-4.

12 The Collaborative Study on the Genetics of Asthma. A genome-wide search for asthma susceptibility loci in ethnically diverse populations. Nat Genet 1997;15:389-92.

13 Rosenwasser LJ, Klemm DJ, Dresback JK, et al. Promoter polymorphisms in the chromosome 5 gene cluster in asthma and atopy. Clin Exp Allergy 1995;2:74-8.

14 Coleman R, Trembath RC, Harper JI. Chromosome 11q13 and atopy underlying atopic eczema. Lancet 1993;341: 1121-2.

15 Mao XQ, Shirakawa T, Yoshikawa T, et al. Association between genetic variants of mast-cell chymase and eczema. Lancet 1996;348:581-3.

16 Hanifin J, Rajka G. Diagnostic features of atopic dermatitis Acta Derm Venereol 1980;suppl:44.

17 Holmans P, Clayton D. Efficiency of typing unaffected relatives in an affected-sib-pair linkage study with single-locus and multiple tightly linked markers. Am $\mathcal{f}$ Hum Genet 1995;57:1221-32

18 Kruglyak L, Daly MJ, Reeve-Daly MP, et al. Parametric and non parametric linkage analysis: a unified multipoint approach. Am f Hum Genet 1996;58:1347-63.

19 Lander E, Kruglyak L. Genetic dissection of complex traits: guidelines for interpreting and reporting linkage results. Nat Genet 1995;11:241-7.

20 Walley A, Cookson W. Investigation of an interleukin-4 promoter polymorphism for associations with asthm and atopy. $\mathcal{F}$ Med Genet 1996;33:689-92.

21 Daniels SE, Bhattacharrya S, James A, et al. A genome-wide search for quantitative trait loci underlying asthma. Nature 1996;383:247-50. 